\title{
PERBAIKAN PROSES PRODUKSI KERIPIK GADUNG DI MASYARAKAT PINGGIRAN HUTAN DI KECAMATAN NGLUYU, KABUPATEN NGANJUK
}

\author{
Improving Wild Yam Chips Processing at Forest Boundaries, \\ Ngluyu District, Nganjuk Regency \\ Harijono $^{1)}$, Feronika Heppy Sriherfyna ${ }^{1)}$ \\ ${ }^{1)}$ Program Studi Ilmu dan Teknologi Pangan - Universitas Brawijaya Jl. Veteran, Malang \\ Email: harijono@ub.ac.id
}

\begin{abstract}
The processing of wild yam chips is done by people surrounding teak and mahogany forest in District Ngluyu, Nganjuk Regency. Problems exist in the production of yam chips is manual slicing and pressing, small capacity of steaming, and sun drying. The solutions offered to solve these problems are transfer of technology or mechanization of processing wlid yam chips. Results showed increasing efficiency and capacity of pressing, slicing, drying, and steaming wild yam chips. Increasing production capacity in the slicing process is because of the mechanization by using chopper machine. The drying efficiency is achieved with the use of the cabinet dryer so that the partners did not experience weather constraints. Increasing production capacity is also achieved in steaming.
\end{abstract}

Keywords: drying, forest stands, pressing, slicing, steaming, wild yam

\begin{abstract}
ABSTRAK
Proses pengolahan keripik gadung dilakukan oleh para perajin keripik gadung di pinggiran hutan jati dan mahoni di Kecamatan Ngluyu. Permasalahan yang dihadapi pada produksi keripik gadung adalah perajangan, pengepresan yang masih manual, pengukusan kapasitas kecil, dan pengeringan dengan penjemuran. Solusi yang ditawarkan untuk mengatasi permasalahan tersebut adalah alih teknologi atau mekanisasi proses pengolahan keripik gadung. Hasil kegiatan menunjukkan peningkatan efisiensi pengepresan irisan umbi gadung dan kapasitas pengeringan dan pengukusan. Peningkatan kapasitas produksi adalah pada proses pengirisan karena mekanisasi menggunakan mesin perajang yang disesuaikan dengan kebutuhan mitra yaitu berukuran besar dan agak tebal. Efisiensi pengeringan tercapai dengan penggunaan mesin pengering kabinet sehingga mitra tidak mengalami kendala cuaca. Peningkatan kapasitas produksi juga terjadi pada proses pengukusan.
\end{abstract}

Kata kunci: gadung, pengukusan, pengeringan, pengepresan, perajangan, tegakan hutan

\section{PENDAHULUAN}

Gadung merupakan tanaman umbiumbian merambat yang dapat tumbuh di bawah tegakan hutan. Tanaman gadung dapat merambat pada tanaman jati atau mahoni karena untuk tumbuh tanaman ini memerlukan tegakan. Salah satu hutan jati dan mahoni di Jawa Timur adalah kawasan hutan di Kecamatan Ngluyu, Kabupaten Nganjuk. Dinas Kehutanan (Dishut) Kabupaten Nganjuk bekerjasama dengan Perhutani dan LMDH (Lembaga Masyarakat Desa Hutan) Desa Bajang dan Desa Gampeng di Kecamatan Ngluyu telah menanam tanaman gadung di bawah tegakan pohon jati dan mahoni. Tujuan penanaman ini adalah memberikan alternatif hasil hutan bagi masyarakat pinggiran hutan untuk dimanfaatkan secara ekonomi. 
Masyarakat sekitar pinggir hutan di Kecamatan Ngluyu telah memanfaatkan gadung tersebut untuk diolah menjadi keripik gadung. Usaha keripik gadung dilakukan secara berkelompok dengan satu orang bertindak sebagai pengumpul/ penampung. Gadung (Dioscorea hispida) merupakan tanaman keluarga Dioscoreacea atau yam. Penelitian sebelumnya menunjukkan bahwa umbi-umbian keluarga Dioscoreacea (gembili, gadung, ubi kelapa) mempunyai senyawa bioaktif yang berkhasiat obat (Rachman, 2011; Rosyida, 2011; Wulandari, 2012; Estiasih et al., 2012; Harijono et al., 2012a; Harijono et al., 2012b). Hasil-hasil penelitian yang telah ada dari keluarga Dioscoreacea yang lain (D. alata, D. batatas, D. bulbilfera, D. opposita) menunjukkan bahwa keluarga Dioscoreaceae mengandung senyawa bioaktif berupa dioscorin (Hou et al., 2001; Liu et al., 2007; Chan et al., 2006), diosgenin (Chou et al, 2006; Braun, 2008; Yang dan Lin, 2008), dan polisakarida larut air (PLA) (Liu et al., 2008). Gadung mengandung PLA yang dapat menurunkan kadar gula darah pada kondisi hiperglikemia (Estiasih et al., 2012), kolesterol darah (Rosyida, 2011), dan tekanan darah tinggi (Rachman, 2011).

Masalah utama penggunaan umbi gadung sebagai bahan pangan adalah kandungan glikosida sianogenik yang tinggi yang dapat mencapai $182 \mathrm{ppm}$ (Ngasifudin dan Sukosrono, 2006). Glikosida sianogenik dapat terdegradasi menghasilkan HCN (Keresztessy et al., 2001). Kandungan HCN yang tinggi dapat menyebabkan keracunan bagi manusia maupun hewan, sehingga tidak dianjurkan untuk dikonsumsi segar (Sundari, 2010). Hal ini menyebabkan gadung mempunyai keterbatasan pemanfaatan karena sianida merupakan senyawa toksik atau racun yang dapat menyebabkan sesak napas, penurunan tekanan darah, berdebar-debar, lemas, sakit kepala, nyeri perut, muntah-muntah, diare, pusing, dan gemetar (FSANZ, 2005).

Gadung diperoleh dari bawah tegakan hutan kemudian dikupas dan dirajang. Hasil rajangan gadung ditaburi dengan campuran garam kasar dan abu dapur. Selanjutnya, irisan umbi gadung dimasukkan ke dalam karung dan diperam selama semalam. Cairan dari gadung kemudian diperas secara manual, kemudian direndam selama 3 hari. Setiap hari air perendam diganti dengan air baru. Selanjutnya irisan umbi gadung dikukus dan dijemur.

Permasalahan yang dihadapi adalah proses perajangan manual dan memerlukan waktu yang lama yaitu $10 \mathrm{~kg} / \mathrm{jam}$. Mitra menginginkan ada alat pengepres yang dapat membantu mempercepat proses pengepresan. Juga perlu ada peningkatan kapasitas pengukusan dan perbaikan proses pengeringan.

Solusi yang ditawarkan untuk mengatasi permasalahan utama di mitra kelompok perajin keripik gadung di Desa Bajang dan Desa Gampeng adalah alih teknologi atau mekanisasi proses pengolahan keripik gadung. Harapannya proses produksi menjadi lebih efisien, singkat, terkontrol, dan mutu produk baik.

\section{METODE PELAKSANAAN}

Pelaksanaan kegiatan IbM ini ditujukan untuk menyelesaikan masalahmasalah yang dihadapi mitra dalam memproduksi keripik gadung. Metode pelaksanaannya adalah sebagai berikut:

\section{Peningkatan kapasitas perajangan dan keseragaman ketebalan irisan umbi gadung}

Seperti telah dijelaskan sebelumnya, permasalahan yang dihadapi adalah perajangan yang masih manual yang berdampak pada irisan umbi dengan ketebalan tidak seragam dan waktu proses yang lama. Hal ini menyebabkan kapasitas dan efisiensi produksi mitra menjadi rendah. Solusi yang ditawarkan adalah peningkatan kapasitas dan efisiensi perajangan melalui alih teknologi mekanis menggunakan mesin perajang. 


\section{Peningkatan efisiensi pengepresan}

Mitra perajin keripik gadung di Desa Bajang dan Gampeng mempunyai permasalahan dalam pengepresan umbi gadung yang masih tradisional dan manual yaitu irisan umbi yang ditaburi garam dan abu dapur setelah diperam semalam dalam karung dipres dengan cara menggunakan tongkat kayu. Pengepresan ini membutuhkan tenaga yang kuat sehingga hasil pengepresan sangat subyektif, akibatnya hasil pengepresan menjadi tidak seragam. Mitra menginginkan ada teknologi mekanis untuk pengeresan. Selama ini satu kali pengepresan dibutuhkan waktu skeitar 10 menit dengan tenaga yang besar. Dengan alat pengepres hidrolik, waktu yang dibutuhkan untuk pengeresan 1 karung adalah 5 menit dengan tenaga yang jauh lebih sedikit karena proses pengepresan dibantu beban sebesar 20 ton.

\section{Peningkatan kapasitas pengukusan}

Proses pengukusan yang dilakukan mitra saat ini adalah menggunakan dandang skala rumah tanggal berukuran $20 \mathrm{~L}$ yang dapat digunakan untuk mengukus $5 \mathrm{~kg}$ irisan umbi. Kelemahan proses pengukusan selama ini pengukusan lama karena harus dilakukan berulang, dan selama proses pengukusan irisan umbi ditumpuk sehingga memungkinkan irisan umbi menjadi lengket satu sama lain. Setelah dikukus, masingmasing irisan umbi harus ditata untuk dikeringkan.

\section{Peningkatan kinerja pengeringan}

Proses pengeringan merupakan titik kritis pada proses pengolahan keripik gadung. Selama ini mitra mengeringkan irisan umbi gadung yang telah dikukus dengan penjemuran. Penjemuran dalam satu hari harus langsung kering karena jika tertunda sampai keesokan harinya, irisan umbi menjadi cokelat dan warnanya tidak menarik. Pengeringan serentak dengan waktu singkat dibutuhkan mitra untuk menjamin bahwa produk yang dihasilkan bermutu baik dan seragam. Alih teknologi mesin pengering dengan kapasitas 50 $\mathrm{kg} /$ batch dapat mempersingkat proses pengeringan dari satu hari menjadi 3 jam untuk $50 \mathrm{~kg}$.

\section{HASIL DAN PEMBAHASAN}

\section{Peningkatan kapasitas perajangan dan keseragaman ketebalan irisan umbi gadung}

Peningkatan kapasitas dan efisiensi perajangan dilakukan melalui alih teknologi mekanis menggunakan mesin perajang (Gambar 1). Alih teknologi mesin perajang ini dapat meningkatkan kapasitas perajangan dari $10 \mathrm{~kg} / \mathrm{jam}$ menjadi $100 \mathrm{~kg} / \mathrm{jam}$. Hanya saja rancangan alat perajang yang sudh di bawa ke tempat mitra masih ada ketidaksesuaian. Ukuran irisan umbi gadung yang diinginkan mitra adalah sebesar mungkin dan ketebalan sekitar 3 mm. Perajang yang sudah dibuat mempunyai diameter $10 \mathrm{~cm}$ dan ketebalam kurang dari $3 \mathrm{~mm}$. Mitra menginginkan peningkatan ukuran diameter perajang dan ketebalan. Oleh karena itu, desain alat perajang diperbaiki sehingga sesuai dengan kebutuhan mitra.

Perbaikan proses perajang dilakukan dengan mengubah ukuran dan ketebalan irisan, Penggantian pisau cakram dan feeder untuk umbi dilakukan sehingga umbi gadung berukuran besar dapat diiris menggunakan mesin ini. Perajangan umbi gadung berukuran besar dan tebal merupakan selera pasar di wilayah Nganjuk. Akan tetapi kelemahannya proses pengeringan menjadi lebih lama dibandingkan irisan umbi yang lebih kecil dan lebih tipis. 


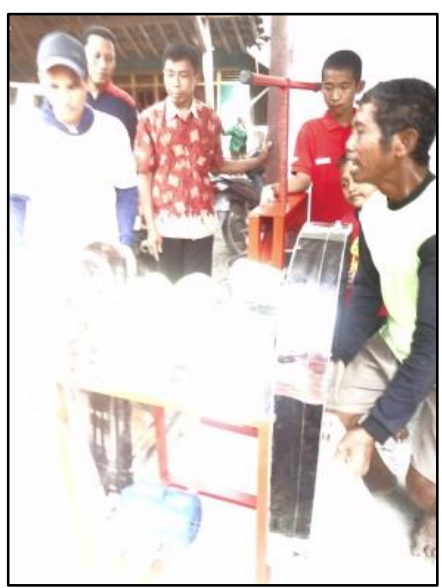

Gambar 1. Mesin perajang umbi gadung

\section{Peningkatan efisiensi pengepresan}

Mitra perajin keripik gadung di Desa Bajang dan Gampeng mempunyai permasalahan dalam pengepresan umbi gadung yang masih tradisional dan manual yaitu irisan umbi yang ditaburi garam dan abu dapur setelah diperam semalam dalam karung dipres dengan cara menggunakan tongkat kayu. Pengepresan ini membutuhkan tenaga yang kuat sehingga hasil pengepresan sangat subyektif, akibatnya hasil pengepresan menjadi tidak seragam.

Proses pengepresan merupakan tahapan pengolahan kritis karena jika pengepresan tidak dapat mengeluarkan cairan dari irisan gadung sebanyak mungkin,

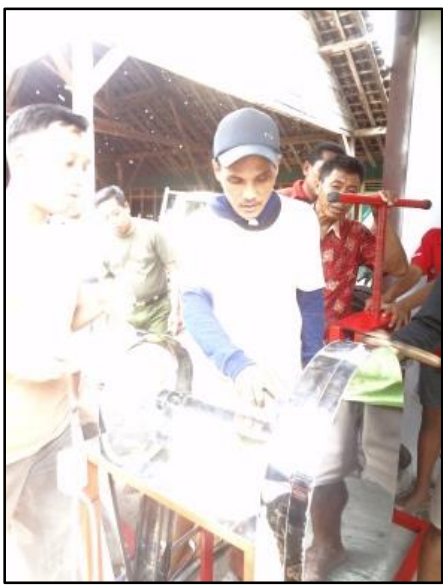

maka residu sianida tidak terbuang dan berisiko terhadap keracunan. Pengepresan manual menyebakan pengeluaran cairan gadung menjadi tidak standar. Pembaluran irisan umbi gadung yang sudah dirajang menggunakna abu dapur dan garam berfungsi meningkatkan tekanan osmotik di luar sel sehingga cairan sel keluar. Proses pengepresan membantu mengeluarkan cairan tersebut. Cairan tersebut mengandung sianida karena sianida di dalam gadung berada di dalam vakuola sel. Mesin pengepres seperti ditunjukkan pada Gambar 2 dapat digunakan untuk membantu mitra dalam proses pengepresan.
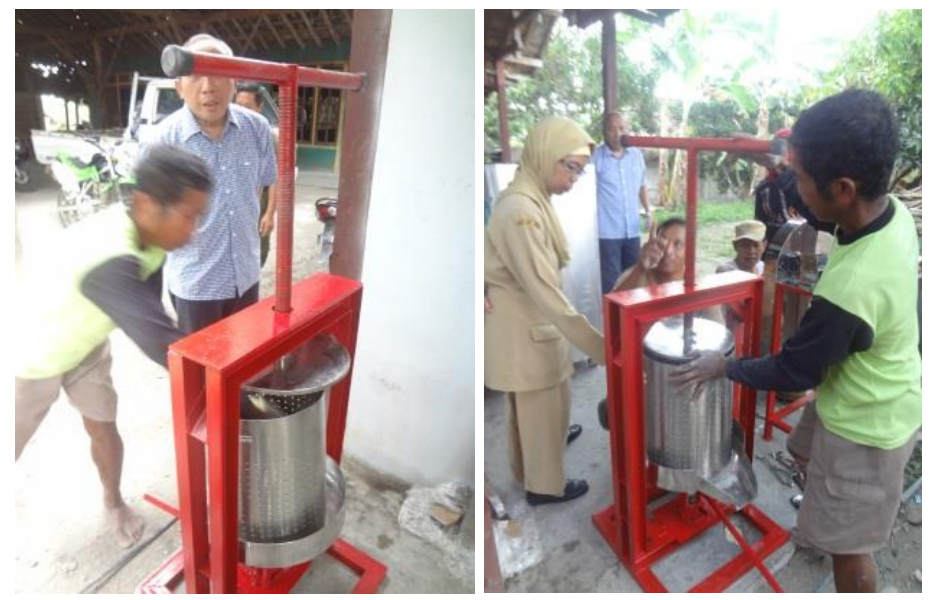

Gambar 2. Mesin pengepres hidrolik 

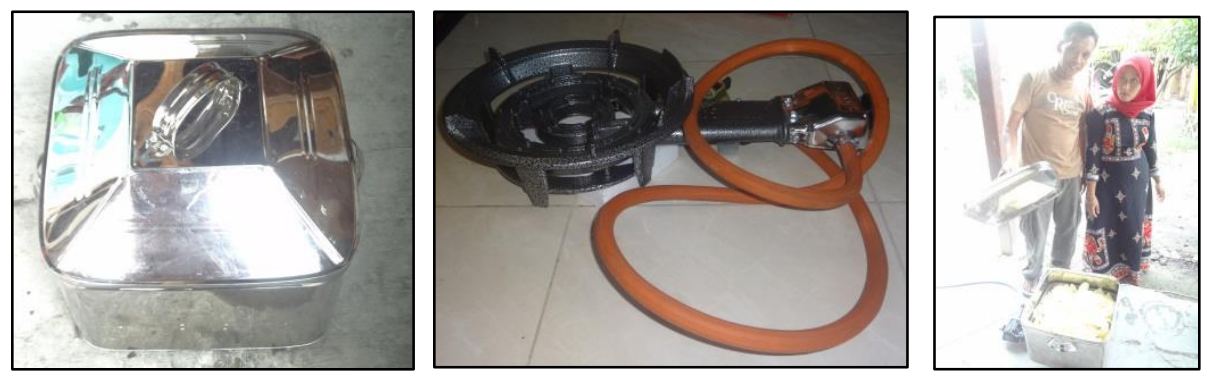

Gambar 3. Panci pengukus dan kompor cor industri

Mesin pengepres ini mempunyai prinsip kerja pemberian beban sehingga terjadi tekanan hidrolik yang mengakibatkan cairan sel keluar. Pengoperasian alat ini dilakukan secara manual, yaitu tongkat bagian atas pengepres diputar untuk menekan irisan umbi gadung. Setelah stabil dan tongkat tidak bisa diputar lagi, dilakukan pemberian teana hidrolik dari bagian bawah dengan bantuan tuas. Dengan cara ini, pemberian tekanan menjadi maksimum untuk mengeluarkan cairan dari irisan umbi gadung sebanyak mungkin. Dalam satu kali pengoperasian, jumlah irisan umbi gadung yang bisa dipres mencapai $5 \mathrm{~kg}$. Keunggulan penggunaan alat ini adalah tenaga yang dikeluarkan pada proses pengeresan tidak sebesar pengepresan manual dengan tongkat kayu, karena dengan pengepres hidrolik ini ada pemberian beban berat dari alat.

\section{Peningkatan kapasitas pengukusan}

Proses pengukusan yang dilakukan mitra saat ini adalah menggunakan dandang skala rumah tanggal berukuran $20 \mathrm{~L}$ yang dapat digunakan untuk mengukus $5 \mathrm{~kg}$ irisan umbi. Kelemahan proses pengukusan selama ini pengukusan lama karena harus dilakukan berulang, dan selama proses pengukusan irisan umbi ditumpuk sehingga memungkinkan irisan umbi menjadi lengket satu sama lain. Setelah dikukus, masingmasing irisan umbi harus ditata untuk dikeringkan.

Peningkatan kapasitas pengukusan dilakukan dengan menambah panci pengukus dan kompor cor industri. Kompor cor industri dengan api besar dapat mengukus irisan umbi gadung dengan kapasitas besar. Adanya beberapa pengukus dengan yang sudah dimiliki mitra, maka kapasitas pengukusan dapat meningkat.

\section{Peningkatan kinerja pengeringan}

Proses pengeringan merupakan titik kritis pada proses pengolahan keripik gadung. Selama ini mitra mengeringkan irisan umbi gadung yang telah dikukus dengan penjemuran. Penjemuran dalam satu hari harus langsung kering karena jika tertunda sampai keesokan harinya, irisan umbi menjadi cokelat dan warnanya tidak menarik. Pengeringan serentak dengan waktu singkat dibutuhkan mitra untuk menjamin bahwa produk yang dihasilkan bermutu baik dan seragam.

Alih teknologi mesin pengering 6 rak dengan kapasitas $30 \mathrm{~kg} /$ batch dapat mempersingkat proses pengeringan dari satu hari menjadi 3 jam untuk $30 \mathrm{~kg}$. Adanya blower dalam alat dan kontrol suhu menyebabkan proses pengeirngan berjalan cepat dan suhu terkendali. Mesin pengering yang akan diintroduksikan ke mitra dapat dilihat pada Gambar 4. Suhu yang digunakan utnuk pengeringan irisan umbi gadung maksimum adalah $50^{\circ} \mathrm{C}$. Alat pengering yang diberikan dapat dimodifikasi menggunakan kayu bakar yang dapat diambil dari sekitar hutan.

Peningkatan efisiensi dan kapasitas produksi setelah alih teknologi mekanis ditangkum pada Tabel 1. 


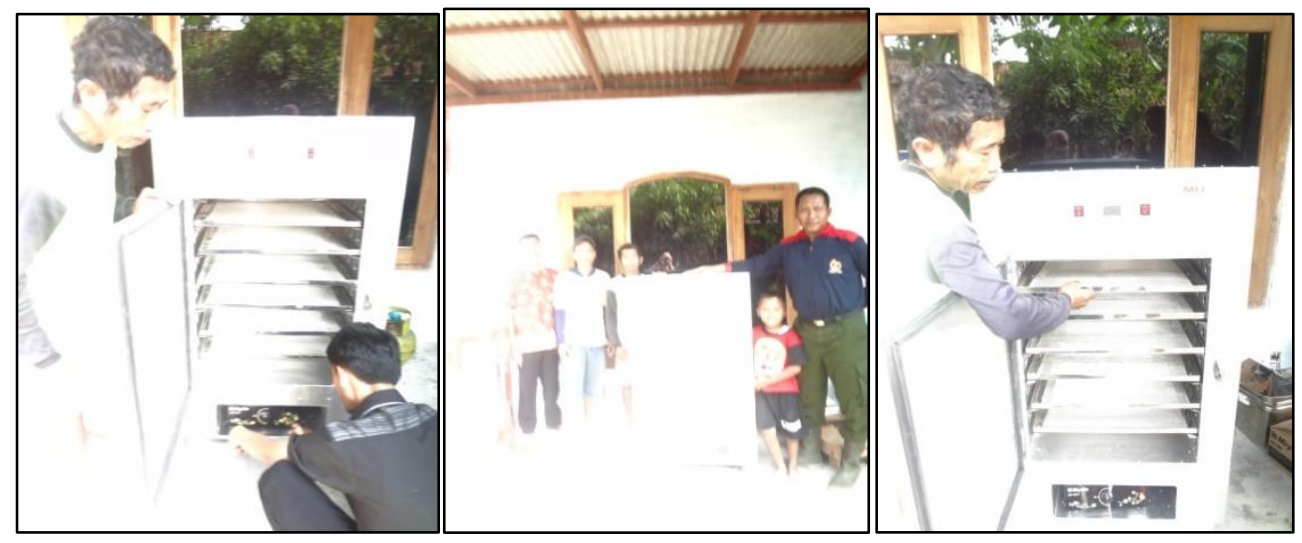

Gambar 4. Mesin pengering tipe kabinet

Tabel 1. Perbandingan efisiensi dan kapasitas produksi sebelum dan setelah alih teknologi melalui Program IbM

\begin{tabular}{llcc}
\hline No. & Tahapan & Kondisi Saat Ini dengan Produksi & Estimasi Setelah Program \\
\hline 1. & Perajangan & $10 \mathrm{~kg} / \mathrm{jam}$ & Perbaikan alat \\
2. & Pengepresan & $1 \mathrm{karung}$, tenaga besar & $1 \mathrm{karung}$, efisien tenaga \\
3. & Pengukusan & $5 \mathrm{~kg} / \mathrm{batch}$ & $10 \mathrm{~kg} / \mathrm{batch}$ \\
4. & Pengeringan & $50 \mathrm{~kg} / 1-2 \mathrm{hari}$ & $30 \mathrm{~kg} / 3 \mathrm{jam}$ \\
\hline
\end{tabular}

\section{KESIMPULAN}

Capaian dari program IbM ini adalah peningkatan efisiensi proses produksi keripik gadung mentah. Peningkatan kapasitas produksi adalah pada proses pengirisan karena mekanisasi menggunakan mesin perajang yang disesuaikan dengan kebutuhan mitra yaitu berukuran besar dan agak tebal. Efisiensi pengeringan tercapai dengan penggunaan mesin pengering kabinet sehingga mitra tidak mengalami kendala cuaca. Peningkatan kapasitas produksi juga terjadi pada proses pengukusan.

\section{UCAPAN TERIMA KASIH}

Penulis mengucapkan terima kasih atas dana Iptek bagi Masyarakat dari Direktorat Penelitian dan Pengabdian kepada Masyarakat, Direktorat Jenderal Pendidikan Tinggi, Kementerian Riset, Teknologi dan Pendidikan Tinggi dengan Nomor Penugasan: 019/SP2H/ PPM/DRPM/II/2016 tanggal 18 Februari
2016, serta Lembaga Penelitian dan Pengabdian kepada Masyarakat (LPPM) Universitas Brawijaya.

\section{DAFTAR PUSTAKA}

Braun L. (2008). Wild Yam Dioscorea sp. Complementary Medicine March/ April

ChanY-C, C-K. Hsu, M-F. Wang, J-W Liao, and T-Y.Su. (2006). Beneficial effect of yam on the amyloid $\beta$ protein, monoamine oxidase $b$ and cognitive deficit in mice with accelerated senescence. J.Sci. Food Agric. 86: 1517-1525

Chou S-T, B-H Chiang, Y-C Chung, P-C. Chen, and C-K Hsu. (2006). Effects of storage temperatures on the antioxidative activity and composition of yam. Food Chemistry 98: 618-623

FSANZ. (2005). Cyanogenic Glycosides in Cassava and Bamboo Shoots. A Human Health Risk Assessment 
Technical Report Series No 28. Food Standards Australia New Zealand

Harijono, T Estiasih, W B Sunarharum, dan IK Suwita. (2012a). Efek hipoglikemik polisakarida larut air gembili (dioscorea esculenta) yang diekstrak dengan berbagai metode. Jurnal Teknologi dan Industri Pangan XXIII (1): 1-8

Harijono, T Estiasih, WB Sunarharum, and MD Hartono. (2012b). Hypoglycaemic Effect of Biscuit Containing Alginate and Water Soluble Polysaccharides from Gembili or Gadung Tubers. Proses Penerbitan International Food Research Journal

Hou W C, M H Lee, H J Chen, WL Liang, $\mathrm{C} \mathrm{H}$ Han, YW Liu, and $\mathrm{Y} \mathrm{H}$ Lin, (2001). Antioxidant activities of dioscorin, the storage protein of yam (Dioscorea batatas Decne.) tuber. J of Agricultural and Food Chemistry 49: 4956-4960

Keresztessy Z, K Brown, M A Dunn, and MA Hughes. (2001). Identification of essential active-site residue in the cyanogenic $\beta$-glucosidase (linamarase) from cassava (manihot esculenta crantz) by site-direct mutagenesis. $J$. Biochem. 353: 199-205

Liu, Y-W, H-F Shang, C-K Wang, F-L Hsu, and W-C Hou. (2007). immunomodulatory activity of dioscorin, the storage protein of yam (Dioscorea alata cv.) Tainong no.1 tuber. Food and Chemical Toxicology 45: 2312-2318

Liu DZ, HJ Liang, CH Han, S Y Lin, C T Chen, M Fan, and WC Hou. (2008). Feeding trial of instant food containing lyophilized yam powder in hypertensive subjects. J. Sci. Food Agric. 89: 138-143

Ngasifudin dan Sukosrono. (2006). Penentuan Efisiensi Penghilangan Sianida pada Pengolahan Umbi
Gadung (Dioscorea hispida). Seminar SDM II, SDM Teknologi Nuklir, Yogyakarta 21-22 Desember

Pitoi M M, A D Wuntu, dan H S J Koleangan. (2008). Detoksifikasi sianida pada tailing tambang emas dengan natrium metabisulfit $\left(\mathrm{Na}_{2} \mathrm{~S}_{2} \mathrm{O}_{5}\right)$ dan hidrogen peroksida $\left(\mathrm{H}_{2} \mathrm{O}_{2}\right)$. Chem. Prog. 1(1): 30-35

Rachman F. (2011). Efek Antihipertensi Dioscorin yang Terikat pada Ekstrak Polisakarida Larut Air Gadung (Dioscorea hispida Dennst.) secara In Vivo. Skirpsi. Universitas Brawijaya, Malang

Rosyida N N. (2011). Efek Hipokolesterolemik Polisakarida Larut Air dari Gadung (Dioscorea hispida Dennst.) yang Diekstrak dengan Berbagai Metode. Skripsi. Universitas Brawijaya, Malang

Sundari T. (2010). Petunjuk Teknis Pengenalan Varietas Unggul dan Teknik Budidaya Ubi Kayu (Materi Pelatihan Agribisnis Bagi KMPH). Report No. 55.STE. Final. Balai Penelitian Kacang Kacangan dan Umbi Umbian, Malang

Winugroho, M A Abrar, dan K G Wiryawan. (2001). Detoksifikasi Sianida oleh Mikroba Rumen (Bioplus Racun). Seminar Nasional Teknologi Peternakan dan Veteriner

Wulandari I. (2012). Beras Analog Berbasis Umbi Gadung (Dioscorea hispida Dennst) dan Alginat sebagai Pangan Berkhasiat Obat (Medicinal Foods) bagi Penderita Diabetes yang Diujikan secara In-Vivo. Skripsi. Universitas Brawijaya. Malang

Yang D-J and J-T Lin. (2008). Effects of different storage conditions on steroidal saponins in yam (Dioscorea pseudojaponica Yamamoto) tubers. Food Chemistry 110: 670-677 